\title{
Factors related to the effectiveness of hypercholesterolemia treatment following hospitalization for coronary artery disease
}

\author{
Piotr Jankowski ${ }^{1}$, Danuta Czarnecka ${ }^{1}$, Anna Łukaszewska ${ }^{1}$, Radosław Łysek ${ }^{2}$, \\ Renata Wolfshaut-Wolak ${ }^{2}$, Piotr Bogacki ${ }^{3}$, Janusz Grodecki ${ }^{4}$, Ewa Mirek-Bryniarska ${ }^{5}$, \\ Jadwiga Nessler ${ }^{6}$, Piotr Podolec ${ }^{7}$, Kalina Kawecka-Jaszcz ${ }^{1}$, Andrzej Pająk ${ }^{2}$ \\ 1 I Department of Cardiology, Interventional Electrocardiology and Hypertension, Institute of Cardiology, Jagiellonian University Medical College, Kraków, Poland \\ 2 Department of Clinical Epidemiology and Population Studies, Institute of Public Health, Jagiellonian University Medical College, Kraków, Poland \\ Department of Cardiology, Ludwik Rydygier District Hospital, Kraków, Poland \\ 4 Department of Cardiology, Gabriel Narutowicz Memorial General Hospital, Kraków, Poland \\ 5 Department of Cardiology, Józef Dietl Hospital, Kraków, Poland \\ 6 Department of Coronary Heart Disease, Institute of Cardiology, Jagiellonian University Medical College, Kraków, Poland \\ 7 Department of Cardiac and Vascular Diseases, Institute of Cardiology, Jagiellonian University Medical College, Kraków, Poland
}

\section{KEY WORDS}

cardiovascular risk, cholesterol, coronary artery disease, secondary prevention
Correspondence to: Prof. Piotr Jankowski, MD, PhD, I Klinika Kardiologii, Elektroterapi Interwencyjnej i Nadciśnienia Tętniczego, Uniwersytet Jagielloński, Collegium Medicum, ul. Kopernika 17, 31-501 Kraków, Poland,

phone: +48 124247300 , e-mail: piotrjankowski@interia.pl Received: March 23, 2016. Revision accepted: May 24, 2016 Published online: June 23, 2016. Conflict of interest: none declared. Pol Arch Med Wewn. 2016; 126 (6): 388-394 doi:10.20452/pamw.3447 Copyright by Medycyna Praktyczna, Kraków 2016

\section{ABSTRACT}

INTRODUCTION Patients with established coronary artery disease (CAD) are at high risk of recurrent cardiovascular events.

OBJECTIVES The aim of the study was to identify factors related to control of hypercholesterolemia in patients after hospitalization for CAD.

PATIENTS AND METHODS The study included consecutive patients from 5 hospitals with cardiology departments serving one city in southern Poland. Patients were hospitalized for an acute coronary syndrome or for a myocardial revascularization procedure. Interviews and examinations were conducted 6 to 18 months after hospitalization.

RESULTS Overall, $83.6 \%$ of the patients were taking statins; $2.1 \%$, fibrates; and $0.5 \%$, ezetimibe. A statin at a high dose ( $\geq 40 \mathrm{mg}$ of atorvastatin or $\geq 20 \mathrm{mg}$ of rosuvastatin) was taken by $36.1 \%$ of the participants. Younger age and index hospitalization in a teaching hospital were significantly associated with a higher probability of taking a statin. Overall, $28.1 \%$ of the patients had good control of hypercholesterolemia (low-density lipoprotein [LDL] cholesterol levels $<1.8 \mathrm{mmol} /$ ), whereas $71.9 \%, 38.6 \%, 24.4 \%$, and $10.3 \%$ had LDL cholesterol levels of $1.8 \mathrm{mmol} / \mathrm{l}$ or higher, $2.5 \mathrm{mmol} / \mathrm{l}$ or higher, $3.0 \mathrm{mmol} / \mathrm{l}$ or higher, and 4.0 $\mathrm{mmol} / \mathrm{l}$ or higher, respectively. Younger age, high blood pressure, and high fasting glucose levels were related to a higher probability of having LDL cholesterol levels of $1.8 \mathrm{mmol} / \mathrm{l}$ or higher, while younger age, shorter period of education, professional inactivity, lack of cardiac rehabilitation, and high blood pressure were related to the probability of $L D L$ cholesterol levels of $4.0 \mathrm{mmol} / \mathrm{l}$ or higher.

CONCLUSIONS The frequency of statin use is affected by age and health care-related factors, while control of hypercholesterolemia after hospitalization due to $C A D$ is dependent mainly on patient-related and clinical factors.

INTRODUCTION Patients with established coronary artery disease (CAD) are at high risk of recurrent cardiovascular events. Despite advances in pharmacological and invasive treatment methods, a number of risk factors remain independent predictors of cardiovascular mortality in patients with CAD. ${ }^{1,2}$ One of the most important risk factors is hypercholesterolemia, while the use of statins is related to improved prognosis. The European guidelines recommend lowering low-density lipoprotein (LDL) cholesterol levels below $1.8 \mathrm{mmol} / \mathrm{l}$ in all coronary patients. ${ }^{3,4}$ 
Despite the overwhelming evidence of the benefits of lowering cholesterol levels, especially when using statins, a majority of patients with CAD still have LDL cholesterol levels above the treatment target. ${ }^{5-10}$ Moreover, although high-dose statins should be prescribed to survivors of acute coronary syndromes, most patients take lower doses. ${ }^{11}$

Furthermore, several factors influencing the quality of secondary prevention in everyday practice have been identified. ${ }^{6,12}$ Nevertheless, identifying the remaining barriers to effective risk factor control is essential to maximize the benefit of preventive interventions. A number of intervention methods aimed at improving secondary prevention in patients with CAD have been proposed to date..$^{13-19}$ However, in order to achieve the maximum benefit from these interventions, their intensity and complexity should be adjusted according to specific populations or even according to specific patients. ${ }^{20}$ Therefore, the aim of our study was to identify factors related to control of LDL cholesterol levels in patients after hospitalization due to CAD.

PATIENTS AND METHODS The study population and the methods used have been described in earlier reports. ${ }^{5,6} \mathrm{~A}$ brief description is given below.

Five hospitals serving one city and surrounding districts in southern Poland participated in the survey. The total population in this area is around 1200000 inhabitants. In each cardiac department, medical records were reviewed and consecutive patients who had been hospitalized for acute myocardial infarction, unstable angina, percutaneous coronary intervention or were scheduled for coronary artery bypass grafting were retrospectively identified, excluding those who had died during their in-hospital stays. Participants were invited to take part in a followup examination 6 to 18 months after discharge. The interviews were started in July 2011 and finished in May 2013. About 64\% of the participants included in the present analysis agreed to have their data and blood samples transferred to the EUROASPIRE IV survey. ${ }^{7}$

Data on demographic characteristics, personal history of CAD, smoking status, blood pressure, fasting glucose levels, plasma lipid levels, and prescribed medications were obtained using a standardized data collection form. Patients had their height and weight measured in a standing position without shoes and heavy outer garments, using standard scales with a vertical ruler. The body mass index (BMI) was calculated according to the following formula: $\mathrm{BMI}=$ weight $[\mathrm{kg}] /(\text { height }[\mathrm{m}])^{2}$. Blood pressure was measured twice on the right arm in a sitting position after at least 5-minute rest. For plasma lipid and glucose measurements, a fasting venous blood sample was taken between 7:30 AM and 8:30 AM.

For the purposes of the present analysis, we divided the study group according to LDL cholesterol levels $(<1.8 \mathrm{mmol} / \mathrm{l}$ vs $1.8-3.9 \mathrm{mmol} / \mathrm{l}$ vs $\geq 4.0 \mathrm{mmol} / \mathrm{l})$.
Statistical analysis Categorical variables were reported as percentages and continuous variables as means $\pm S D$. The Pearson $\chi^{2}$ test was applied to all categorical variables. Normally distributed continuous variables were compared using the $t$ test or analysis of variance. Variables without normal distribution were evaluated using the Mann-Whitney test or the Kruskal-Wallis analysis of variance, as appropriate. The multivariate analyses were performed using the logistic regression analysis as implemented in the STATISTICA 8.0 software (StatSoft Inc., Tulsa, Oklahoma, United States). A 2-tailed $P$ value of less than 0.05 was regarded as indicating statistical significance.

RESULTS Based on the review of hospital records, 1061 patients were invited to a follow-up interview and examination 6 to 18 months after discharge. Data on 562 patients were included in the present analysis (445 patients did not take part in the interview and 54 did not agree to blood collection). A possible selection bias in the formation of the study population was examined by comparing age, sex, risk factors, and the prescription rate of drugs on discharge between the study population and the 499 patients that could not be included in the analysis. The comparison did not reveal any significant differences with respect to the above factors except for age at the time of hospitalization (63.6 \pm 8.8 years in analyzed patients vs $64.9 \pm 10.3$ years in nonanalyzed patients; $P<0.05$ ) and a prescription rate of angiotensin-converting enzyme inhibitors/sartans on discharge $(88.0 \%$ in analyzed patients vs $83.8 \%$ in nonanalyzed patients; $P<0.05$ ). We also compared the attendance rates of the index event groups, which showed a slight but significant bias $(P<0.05)$ characterized by a somewhat higher attendance rate in the percutaneous coronary intervention group. The mean time between discharge and the follow-up interview was $1.1 \pm 0.2$ years.

The characteristics of the analyzed groups are presented in TABLE 1. Patients with high LDL cholesterol levels were younger, less well educated, more likely to be smokers, more likely to have high blood pressure, and were more frequently obese. Overall, $83.6 \%$ of the patients were taking statins; $2.1 \%$, fibrates; and $0.5 \%$, ezetimibe (TABLE 2). Among all study participants, $55.5 \%$ were taking atorvastatin; $17.4 \%$, simvastatin; and $10.7 \%$, rosuvastatin. A statin at a high dose ( $\geq 40 \mathrm{mg}$ of atorvastatin or $\geq 20 \mathrm{mg}$ of rosuvastatin) was taken by $36.1 \%$ of the patients. When $80 \mathrm{mg}$ of simvastatin was also taken into account, the proportion increased to $36.7 \%$.

The variables independently related to statin use are presented in TABLE 3 . The same factors were significantly related to the use of a lipid-lowering drug (data not shown). The only significant variable related to the use of fibrates was the duration of education (odds ratio [OR], 1.19; 95\% confidence interval [CI], 1.02-1.38). 
TABLE 1 Characteristics of the study group

\begin{tabular}{|c|c|c|c|c|c|c|c|}
\hline \multirow{2}{*}{\multicolumn{3}{|c|}{ Parameter }} & \multicolumn{3}{|c|}{ LDL cholesterol, mmol// } & \multirow[t]{2}{*}{$P$ value } & \multirow{2}{*}{$\begin{array}{l}\text { Total } \\
(\mathrm{n}=562)\end{array}$} \\
\hline & & & $\begin{array}{l}<1.8 \\
(n=158)\end{array}$ & $\begin{array}{l}1.8-3.9 \\
(n=346)\end{array}$ & $\begin{array}{l}\geq 4.0 \\
(n=58)\end{array}$ & & \\
\hline \multicolumn{3}{|l|}{ age, $y$, mean \pm SD } & $66.3 \pm 8.8$ & $64.5 \pm 9.0$ & $62.7 \pm 8.2$ & 0.01 & $64.8 \pm 8.9$ \\
\hline \multirow{2}{*}{\multicolumn{2}{|c|}{ sex, \% }} & men & 69.0 & 63.3 & 58.6 & \multirow[t]{2}{*}{0.29} & 64.4 \\
\hline & & women & 31.0 & 36.7 & 41.4 & & 35.6 \\
\hline \multicolumn{3}{|c|}{ duration of education, $y$, mean $\pm S D$} & $11.9 \pm 3.4$ & $12.0 \pm 3.3$ & $10.9 \pm 2.6$ & $<0.01$ & $11.9 \pm 3.3$ \\
\hline \multicolumn{3}{|l|}{ professionally active, $\%$} & 17.8 & 24.8 & 8.6 & 0.01 & 21.1 \\
\hline \multirow{4}{*}{\multicolumn{2}{|c|}{ index event, \% }} & $\begin{array}{r}\text { myocardial } \\
\text { infarction }\end{array}$ & 39.2 & 37.0 & 19.0 & \multirow[t]{4}{*}{0.02} & 32.6 \\
\hline & & unstable angina & 31.0 & 30.1 & 51.7 & & 35.8 \\
\hline & & $\mathrm{PCl}$ & 22.8 & 22.5 & 24.1 & & 22.8 \\
\hline & & CABG & 7.0 & 10.4 & 5.2 & & 8.9 \\
\hline \multirow{2}{*}{\multicolumn{2}{|c|}{ index hospitalization, \% }} & teaching hospital & 56.3 & 65.3 & 51.7 & \multirow[t]{2}{*}{0.04} & 61.4 \\
\hline & & other hospital & 43.7 & 34.7 & 48.3 & & 38.6 \\
\hline \multirow{2}{*}{\multicolumn{2}{|c|}{$\begin{array}{l}\text { cardiac rehabilitation after index } \\
\text { hospitalization, \% }\end{array}$}} & yes & 32.1 & 31.6 & 14.0 & \multirow[t]{2}{*}{0.02} & 29.9 \\
\hline & & no & 67.9 & 68.4 & 86.0 & & 70.1 \\
\hline \multicolumn{3}{|c|}{ diabetes diagnosed during index hospitalization, $\%$} & 37.3 & 27.7 & 24.1 & 0.05 & 30.1 \\
\hline \multicolumn{3}{|c|}{ hypertension diagnosed during index hospitalization, \% } & 81.0 & 82.7 & 82.8 & 0.90 & 82.2 \\
\hline \multirow[t]{4}{*}{ practice setting, \% } & \multicolumn{2}{|c|}{$\begin{array}{l}\text { hospital outpatient clinic/ } \\
\text { cardiologist }\end{array}$} & 81.4 & 78.2 & 77.6 & \multirow[t]{4}{*}{0.57} & 79.0 \\
\hline & \multicolumn{2}{|c|}{ general practitioner } & 6.4 & 10.5 & 5.2 & & 8.8 \\
\hline & \multicolumn{2}{|c|}{ private cardiac practice } & 10.3 & 9.6 & 15.5 & & 10.4 \\
\hline & \multicolumn{2}{|c|}{ no regular health check-up } & 1.9 & 1.7 & 1.7 & & 1.8 \\
\hline \multicolumn{3}{|l|}{ smoking, \% } & 12.3 & 20.2 & 31.0 & $<0.01$ & 19.2 \\
\hline \multicolumn{3}{|c|}{ blood pressure $\geq 140 / 90 \mathrm{mmHg}, \%$} & 36.2 & 40.2 & 61.8 & $<0.01$ & 41,3 \\
\hline \multicolumn{3}{|c|}{ fasting glucose $\geq 7.0 \mathrm{mmol} / \mathrm{l}, \%$} & 21.5 & 13.0 & 17.5 & 0.05 & 15.9 \\
\hline \multicolumn{3}{|c|}{ body mass index $\geq 30 \mathrm{~kg} / \mathrm{m}^{2}, \%$} & 34.4 & 32.0 & 41.1 & 0.03 & 36.3 \\
\hline \multirow{4}{*}{\multicolumn{2}{|c|}{ lipids, $\mathrm{mmol} / \mathrm{l}$, mean $\pm \mathrm{SD}$}} & total cholesterol & $3.50 \pm 0.71$ & $4.61 \pm 0.78$ & $7.07 \pm 1.12$ & $<0.001$ & $4.55 \pm 1.27$ \\
\hline & & LDL cholesterol & $1.46 \pm 0.27$ & $2.56 \pm 0.57$ & $4.84 \pm 0.68$ & $<0.001$ & $2.48 \pm 1.07$ \\
\hline & & HDL cholesterol & $1.35 \pm 0.49$ & $1.35 \pm 0.40$ & $1.35 \pm 0.30$ & 0.34 & $1.35 \pm 0.42$ \\
\hline & & triglycerides & $1.50 \pm 1.28$ & $1.53 \pm 0.81$ & $2.09 \pm 1.97$ & $<0.001$ & $1.58 \pm 1.14$ \\
\hline
\end{tabular}

Abbreviations: CABG, coronary artery bypass grafting; HDL, high-density lipoprotein; LDL, low-density lipoprotein; PCl, percutaneous coronary intervention

TABLE 2 Treatment of study participants

\begin{tabular}{|c|c|c|c|c|c|}
\hline \multirow[t]{2}{*}{ Parameter } & \multicolumn{3}{|c|}{ LDL cholesterol, mmol/l } & \multirow[t]{2}{*}{$P$ value } & \multirow[t]{2}{*}{ Tota } \\
\hline & $<1.8$ & $1.8-3.9$ & $\geq 4.0$ & & \\
\hline antiplatelets, $\%$ & 93.7 & 91.3 & 81.0 & 0.02 & 90.9 \\
\hline$\beta$-blockers, $\%$ & 84.2 & 81.5 & 70.7 & 0.08 & 81.1 \\
\hline ACEls/sartans, \% & 78.5 & 78.6 & 63.8 & 0.04 & 77.0 \\
\hline calcium antagonists, $\%$ & 26.6 & 23.4 & 27.6 & 0.65 & 24.7 \\
\hline diuretics, $\%$ & 48.1 & 39.0 & 48.3 & 0.10 & 42.5 \\
\hline antismoking drugs ${ }^{\mathrm{a}}, \%$ & 8.3 & 5.9 & 9.1 & 0.48 & 6.9 \\
\hline lipid-lowering drugs, \% & 90.5 & 84.7 & 60.3 & $<0.001$ & 83.8 \\
\hline statins, $\%$ & 90.5 & 84.4 & 60.3 & $<0.001$ & 83.6 \\
\hline fibrates, $\%$ & 3.2 & 1.7 & 1.7 & 0.57 & 2.1 \\
\hline ezetimibe, $\%$ & 1.3 & 0.0 & 1.7 & 0.08 & 0.5 \\
\hline
\end{tabular}

a ever in the period from discharge to the follow-up interview

Abbreviations: ACEl, angiotensin-converting enzyme inhibitor; others, see TABLE 1 


\begin{tabular}{ll} 
Variable & Odds ratio (95\% confidence interval) \\
age, per 10 years & $1.30(1.00-1.68)$ \\
\hline index hospitalization in a teaching hospital; yes -1, no -0 & $2.37(1.48-3.79)$ \\
\hline general practitioner; yes -1, no -0 & $0.35(0.18-0.69)$ \\
\hline
\end{tabular}

Overall, $28.1 \%$ of the patients had target LDL cholesterol levels ( $<1.8 \mathrm{mmol} / \mathrm{l})$, whereas $71.9 \%$, $38.6 \%, 24.4 \%$, and $10.3 \%$ of the patients had LDL cholesterol levels of $1.8 \mathrm{mmol} / 1$ or higher, $2.5 \mathrm{mmol} / \mathrm{l}$ or higher, $3.0 \mathrm{mmol} / \mathrm{l}$ or higher, and $4.0 \mathrm{mmol} / \mathrm{l}$ or higher, respectively. Among participants aged 65 years or younger, $24.7 \%$ had LDL cholesterol levels below $1.8 \mathrm{mmol} / \mathrm{l}$, whereas among those older than 65 years, the proportion was $31.5 \%(P=0.07)$. The corresponding proportions were as follows: $30.1 \%$ among men vs $24.5 \%$ among women ( $P=0.16$ ), and $29.7 \%$ among patients with at least a secondary school education vs $26.6 \%$ in less educated participants $(P=0.42)$. Similarly, $23.7 \%$ of professionally active participants had LDL cholesterol levels below $1.8 \mathrm{mmol} / \mathrm{l}$, in comparison with $29.3 \%$ of those who were professionally inactive $(P=0.23)$. The corresponding proportions were $30.9 \%$ among patients with myocardial infarction as an index diagnosis; $26.8 \%$ in those with unstable angina, $28.1 \%$ in those with percutaneous coronary intervention, and $22.0 \%$ in those with coronary artery bypass grafting $(P=0.61)$.

When we limited the analysis to patients taking a statin, $69.6 \%, 32.3 \%, 18.3 \%$, and $7.4 \%$ had LDL cholesterol levels of $1.8 \mathrm{mmol} / \mathrm{l}$ or higher, 2.5 $\mathrm{mmol} / \mathrm{l}$ or higher, $3.0 \mathrm{mmol} / \mathrm{l}$ or higher, and 4.0 $\mathrm{mmol} / \mathrm{l}$ or higher, respectively. When we limited the analysis to patients taking a high-dose statin, $62.9 \%, 29.5 \%, 19.7 \%$, and $8.9 \%$ had LDL cholesterol levels of $1.8 \mathrm{mmol} / \mathrm{l}$ or higher, $2.5 \mathrm{mmol} / \mathrm{l}$ or higher, $3.0 \mathrm{mmol} / \mathrm{l}$ or higher, and $4.0 \mathrm{mmol} / \mathrm{l}$ or higher, respectively.

The factors related to the lack of adequate control of cholesterol levels are presented in TABLE 4 (univariate analysis) and in TABLE 5 (multivariate analysis). When we excluded other risk factors (smoking, hypertension, high fasting glucose levels) from the multivariate model, the only variable significantly related to the probability of having uncontrolled LDL cholesterol ( $\geq 1.8 \mathrm{mmol} / \mathrm{l})$ was age. Similarly, when we did not include other risk factors into the multivariate model, the following variables were independently related to the probability of having very high LDL cholesterol levels ( $\geq 4.0 \mathrm{mmol} / \mathrm{l})$ : age (OR, 0.47; 95\% CI, $0.33-0.68)$, duration of education (OR, $0.87 ; 95 \%$ CI, 0.79-0.97), professional activity (OR, 0.22; 95\% CI, 0.08-0.64), unstable angina as an index event (OR, 2.53; 95\% CI, 1.41-4.54), and participation in cardiac rehabilitation following the index hospitalization (OR, 0.36; 95\% CI, 0.16-0.80).

DISCUSSION The principal finding of this study is that despite overwhelming evidence that lipid-lowering therapy improves clinical outcomes in patients with CAD, $71.9 \%$ of study participants had LDL cholesterol levels above the recommended target. The majority of these patients probably did not receive proper evaluation and treatment for dyslipidemia following hospitalization due to $C A D$. In general, our results showed a considerable potential for a further reduction in cardiovascular risk following hospitalization for CAD through improvement in the management of hypercholesterolemia.

In the previous report, we used data from patients hospitalized due to CAD between 1996 and 1999 to analyze factors related to the use of lipid-lowering drugs 6 to 18 months after hospitalization due to $\mathrm{CAD}$, and we showed that hospitalization in a teaching hospital almost doubled the likelihood of taking a lipid-lowering drug following hospitalization. ${ }^{20}$ Our present results suggest that this association has not changed since the end of the 20th century despite a number of educational activities organized for physicians and despite profound changes in the Polish society induced by the collapse of the communist system in 1989 and by entering the European Union in 2004. The Poland's health care system has been in transition for the last 20 years, both in terms of institutional changes and regulations regarding drug registration, prescription, and reimbursement. Importantly, the relative position of primary care physicians and specialists has evolved. In this respect, it is worth noting that the relationship between the use of lipid-lowering drugs and practice setting has not changed significantly. ${ }^{20}$

No correlation was observed between a patient's level of education and the probability of having LDL cholesterol levels below $1.8 \mathrm{mmol} / 1$ or below $2.5 \mathrm{mmol} / \mathrm{l}$ following hospitalization due to CAD among participants of the EUROASPIRE IV survey. ${ }^{21}$ Our results are concordant with those reported by Bruthans et al, ${ }^{21}$ as duration of education was not related to the probability of appropriate control of cholesterol levels in our study group. However, we were able to show the independent relationship between duration of education and the probability of having very high LDL cholesterol levels ( $\geq 4.0 \mathrm{mmol} / \mathrm{l})$.

Professional inactivity was the most important factor related to very high LDL cholesterol levels. This might be due to financial barriers but other factors (eg, a number of comorbidities as well as psychological factors) might be also responsible for this finding. Indeed, patients with high LDL cholesterol levels were not only taking lipid-lowering drugs less frequently compared with patients with lower LDL cholesterol levels, 
TABLE 4 Variables related to the probability of having high low-density lipoprotein (LDL) cholesterol level (univariate analysis)

\begin{tabular}{|c|c|c|c|}
\hline \multirow{2}{*}{\multicolumn{2}{|c|}{ Variable }} & \multicolumn{2}{|c|}{ Odds ratio (95\% confidence intervals) } \\
\hline & & $\begin{array}{l}\text { LDL cholesterol } \\
\geq 1.8 \mathrm{mmol} / \mathrm{l}\end{array}$ & $\begin{array}{l}\text { LDL cholesterol } \\
\geq 4.0 \mathrm{mmol} / \mathrm{l}\end{array}$ \\
\hline \multicolumn{2}{|l|}{ age, per 10 years } & $0.76(0.61-0.94)$ & $0.75(0.56-1.02)$ \\
\hline \multicolumn{2}{|c|}{ sex; men - 1, women - 0} & $0.75(0.51-1.12)$ & $0.76(0.44-1.32)$ \\
\hline \multicolumn{2}{|c|}{ duration of education, per 1 year } & $1.00(0.95-1.06)$ & $0.90(0.82-0.98)$ \\
\hline \multicolumn{2}{|c|}{ professional activity; yes -1 , no -0} & $1.33(0.83-2.14)$ & $0.32(0.13-0.83)$ \\
\hline \multirow[t]{4}{*}{ index event } & myocardial infarction; yes -1 , no -0 & $0.81(0.56-1.19)$ & $0.39(0.20-0.77)$ \\
\hline & unstable angina; yes -1 , no -0 & $1.10(0.74-1.64)$ & $2.46(1.42-4.26)$ \\
\hline & PCl; yes - 1, no - 0 & $1.00(0.88-1.13)$ & $1.09(0.58-2.06)$ \\
\hline & CABG; yes -1, no -0 & $1.43(0.71-2.87)$ & $0.53(0.16-1.77)$ \\
\hline \multicolumn{2}{|c|}{ index hospitalization in a teaching hospital; yes -1 , no -0} & $1.34(0.92-1.95)$ & $0.64(0.37-1.11)$ \\
\hline \multicolumn{2}{|c|}{ cardiac rehabilitation following index hospitalization; yes -1 , no -0} & $0.87(0.58-1.30)$ & $0.35(0.16-1.76)$ \\
\hline \multirow[t]{4}{*}{ practice setting } & $\begin{array}{l}\text { hospital outpatient clinic/cardiologist; } \\
\text { yes }-1 \text {, no }-0\end{array}$ & $0.81(0.51-1.30)$ & $0.91(0.47-1.76)$ \\
\hline & general practitioner; yes -1 , no -0 & $1.57(0.76-3.23)$ & $0.54(0.16-1.79)$ \\
\hline & private cardiology practice; yes -1, no -0 & $1.02(0.56-1.87)$ & $1.69(0.78-3.66)$ \\
\hline & no regular health check-up; yes -1, no -0 & $0.90(0.23-3.56)$ & $0.96(0.11-7.98)$ \\
\hline \multicolumn{2}{|c|}{ smoking; yes -1 , no -0} & $1.92(1.14-3.25)$ & $2.07(1.13-3.78)$ \\
\hline \multicolumn{2}{|c|}{ blood pressure $\geq 140 / 90 \mathrm{mmHg}$; yes -1 , no -0} & $1.34(0.91-1.99)$ & $2.53(1.42-4.50)$ \\
\hline \multicolumn{2}{|c|}{ fasting glucose $\geq 7.0 \mathrm{mmol} / \mathrm{l}$; yes -1 , no -0} & $0.58(0.36-0.93)$ & $1.14(0.55-2.36)$ \\
\hline \multicolumn{2}{|c|}{ body mass index $\geq 30 \mathrm{~kg} / \mathrm{m}^{2} ;$ yes -1 , no -0} & $0.95(0.64-1.41)$ & $1.45(0.83-2.53)$ \\
\hline
\end{tabular}

TABLE 5 Variables independently related to the probability of having high low-density lipoprotein (LDL) cholesterol levels (multivariate analysis)

\begin{tabular}{|c|c|c|}
\hline \multirow[t]{2}{*}{ Variable } & \multicolumn{2}{|c|}{ Odds ratio (95\% confidence intervals) } \\
\hline & LDL cholesterol $\geq 1.8 \mathrm{mmol} / \mathrm{l}$ & LDL cholesterol $\geq 4.0 \mathrm{mmol} / \mathrm{l}$ \\
\hline \multicolumn{3}{|l|}{ all patients } \\
\hline age, per 10 years & $0.77(0.62-0.97)$ & $0.46(0.31-0.66)$ \\
\hline sex; men - 1, women - 0 & $0.64(0.43-0.97)$ & - \\
\hline duration of education, per 1 year & - & $0.89(0.80-0.99)$ \\
\hline professionally active; yes -1 , no -0 & - & $0.21(0.07-0.63)$ \\
\hline unstable angina as an index event; yes -1, no -0 & - & $2.62(1.45-4.74)$ \\
\hline $\begin{array}{l}\text { cardiac rehabilitation following the index } \\
\text { hospitalization; yes }-1, \text { no }-0\end{array}$ & - & $0.37(0.17-0.83)$ \\
\hline smoking; yes -1 , no -0 & $1.80(1.04-3.12)$ & - \\
\hline blood pressure $\geq 140 / 90 \mathrm{mmHg}$; yes -1 , no -0 & $1.56(1.04-2.33)$ & $2.50(1.38-4.56)$ \\
\hline fasting glucose $\geq 7.0 \mathrm{mmol} / /$; yes -1 , no -0 & $0.57(0.34-0.93)$ & - \\
\hline \multicolumn{3}{|l|}{ patients taking statins } \\
\hline age, per 10 years & - & $0.39(0.24-0.64)$ \\
\hline professionally active; yes -1 , no -0 & - & $0.04(0.00-0.29)$ \\
\hline $\begin{array}{l}\text { cardiac rehabilitation following index hospitalization; } \\
\text { yes }-1, \text { no }-0\end{array}$ & - & $0.25(0.08-0.76)$ \\
\hline smoking; yes -1 , no -0 & $1.83(1.04-3.23)$ & - \\
\hline blood pressure $\geq 140 / 90 \mathrm{mmHg}$; yes -1 , no -0 & $1.54(1.01-2.36)$ & $3.30(1.52-7.18)$ \\
\hline fasting glucose $\geq 7.0 \mathrm{mmol} / /$; yes -1 , no -0 & $0.55(0.32-0.94)$ & - \\
\hline
\end{tabular}

but they were also taking antiplatelet drugs and angiotensin-converting enzyme inhibitors/sartans less frequently. In addition, control of hypercholesterolemia was related to high blood pressure and smoking. The participation in a cardiac rehabilitation program was not related to the probability of having target LDL cholesterol levels. On the other hand, it was independently related to very high LDL cholesterol levels.

The long time interval since the last coronary event is usually considered as related to nonoptimal secondary medical prevention. Indeed, 
Meurice et $\mathrm{al}^{22}$ showed that after 5 years since the last coronary event, the nonoptimal secondary medical prevention was significantly more frequent. As we assessed secondary prevention about 1 year since the index hospitalization, we could not address this phenomenon.

Study limitations The present study has several limitations. Firstly, it is possible that some unrecognized factors might have influenced the approach to the management of hypercholesterolemia. Secondly, we were not able to assess the impact of the appropriate hypercholesterolemia management on mortality or morbidity. Thirdly, we could not analyze the influence of lifestyle on the LDL cholesterol level. However, statins were shown to be more potent in decreasing cholesterol levels compared with lifestyle changes in high-risk patients. ${ }^{23}$ Nevertheless, both drugs and lifestyle interventions should be used simultaneously in patients with CAD. Fourthly, our study participants were not representative of the entire population of patients with CAD. Participants were limited to those who had experienced an acute $\mathrm{CAD}$ event or a revascularization procedure. Therefore, our results should not be directly applied to other subjects. However, an important strength of our analysis is that our results are not just based on abstracted medical record data but on face-to-face interviews and examinations using the same protocol and standardized methods and instruments, including central laboratory analyses of lipids and glucose. Therefore, this analysis provides reliable information on the effectiveness of hypercholesterolemia management following hospitalization due to CAD.

Conclusions Age and health system-related factors are related to the use of statins, whereas mainly patient-related factors are related to control of hypercholesterolemia following hospitalization due to CAD.

Contribution statement $\mathrm{PJ}$ conceived the idea for the study. PJ, KK-J, and AP contributed to the design of the research. PJ, DC, KK-J, and AP were involved in data collection. PJ analyzed the data. All authors edited and approved the final version of the manuscript.

Acknowledgments The surveys were supported by the Jagiellonian University grant (K/ZDS/002420; to PJ) and the grant of the Polish National Science Centre (No. DEC-2011/03/B/ NZ7/06101; to AP). This publication was supported by the Faculty of Medicine, Jagiellonian University Medical College, Leading National Research Centre (KNOW) 2012-2017.

\section{REFERENCES}

1 De Bacquer D, Dallongeville J, Kotseva K, et al. Residual risk of cardiovascular mortality in patients with coronary heart disease: The EUROASPIRE Risk Categories. Int J Cardiol. 2013; 168: 910-914.

2 Bittner V, Bertolet M, Barraza R, et al. Comprehensive Cardiovascula Risk Factor Control Improves Survival: The BARI 2D Trial. J Am Coll Cardiol. 2015; 66: 765-773

3 Reiner Z, Catapano AL, De Backer G, et al. ESC/EAS Guidelines for the management of dyslipidaemias: the Task Force for the management of dyslipidaemias of the European Society of Cardiology (ESC) and the European Atherosclerosis Society (EAS). Eur Heart J. 2011; 32: 1769-1818.

4 European Guidelines on cardiovascular disease prevention in clinical practice (version 2012). The Fifth Joint Task Force of the European Society of Cardiology and Other Societies on Cardiovascular Disease Prevention in Clinical Practice. Eur Heart J. 2012; 33: 1635-1701.

5 Jankowski P, Czarnecka D, tysek R, et al. Secondary prevention in patients after hospitalization due to coronary artery disease: what has changed since 2006? Kardiol Pol. 2014; 72: 355-362.

6 Jankowski P, Czarnecka D, Wolfshaut-Wolak R, et al. Secondary prevention of coronary artery disease in contemporary clinical practice. Cardiol J. 2015; 22: 219-226

7 Kotseva K, Wood D, De Bacquer D, et al. EUROASPIRE IV: A European Society of Cardiology survey on the lifestyle, risk factor and therapeutic management of coronary patients from 24 European countries. Eur J Prev Cardiol. 2016; in press.

8 Opolski G, Strojek K, Kurzelewski M, et al. Cardiovascular therapy, diagnostic procedures, and control of risk factors in patients with diabetes or coronary artery disease in Poland: the Kardia-Pol registry. Pol Arch Med Wewn. 2012; 122: 413-421.

9 Truthmann J, Busch MA, Scheidt-Nave C, et al. Modifiable cardiovascular risk factors in adults aged 40-79 years in Germany with and without prior coronary heart disease or stroke. BMC Public Health. 2015; 15: 701.

10 Rosenson RS, Kent ST, Brown TM, et al. Underutilization of high-intensity statin therapy after hospitalization for coronary heart disease. J Am Coll Cardiol. 2015; 65: 270-277.

11 Kubica A, Kasprzak M, Obońska K, et al. Discrepancies in assessment of adherence to antiplatelet treatment after myocardial infarction. Pharmacology. 2015; 95: 50-58

12 Piepoli MF, Benzer W, Bjarnason-Wehrens B, et al. Secondary prevention through cardiac rehabilitation: from knowledge to implementation. A position paper from the Cardiac Rehabilitation Section of the European Association of Cardiovascular Prevention and Rehabilitation. Eur J Cardiovasc Prev Rehabil. 2010; 17: 1-17.

13 Harris MF, Parker SM, Litt J, et al. Implementing guidelines to routinely prevent chronic vascular disease in primary care: the Preventive Evidence into Practice cluster randomised controlled trial. BMJ Open. 2015; 5: e009397.

14 Devi R, Singh SJ, Powell J, et al. Internet-based interventions for the secondary prevention of coronary heart disease. Cochrane Database Sys Rev. 2015; 12: CD009386.

15 Jakobsson S, Irewall AL, Bjorklund F, et al. Cardiovascular secondary prevention in high-risk patients: a randomized controlled trial sub-study. BMC Cardiovasc Disord. 2015; 15: 125.

16 Murphy AW, Cupples ME, Murphy E, et al. Six-year follow-up of the SPHERE RCT: secondary prevention of heart disease in general practice. BMJ Open. 2015; 5: e007807.

17 Thomas RJ. The gap in cardiac rehabilitation referral: a system based problem with system-based solutions. J Am Coll Cardiol. 2015; 65 2089-2090

18 Snaterse M, Dobber J, Jepma P, et al. Effective components of nursecoordinated care to prevent recurrent coronary events: a systematic review and meta-analysis. Heart. 2016; 102: 50-56.

19 Jankowski P, Pajak A, Lysek R, et al. Cardiac Rehabilitation in Real Life. Medicine (Baltimore). 2015; 94: e1257.

20 Kawecka-Jaszcz K, Jankowski P, Pajak A. Determinants of appropriate lipid management in patients with ischaemic heart disease. Cracovian Program for Secondary Prevention of Ischaemic Heart Disease. Int J Cardiol. 2003; 91: 15-23.

21 Bruthans J, Mayer $0 \mathrm{Jr}$, De Bacquer D, et al. Educational level and risk profile and risk control in patients with coronary heart disease. Eur J Prev Cardiol. 2016. In press.

22 Meurice T, Tricot 0, Lemesle G, et al. Prevalence and correlates of nonoptimal secondary medical prevention in patients with stable coronary artery disease. Arch Cardiovasc Dis. 2015; 108: 340-346.

23 Grzegorzewska AE, Niepolski L, Sikora J, et al. Effect of lifestyle changes and atorvastatin administration on dyslipidemia in hemodialysis patients: a prospective study. Pol Arch Med Wewn. 2014; 124: 443-451. 


\title{
Czynniki związane z kontrolą hipercholesterolemii u osób po hospitalizacji z powodu choroby niedokrwiennej serca
}

\author{
Piotr Jankowski', Danuta Czarnecka', Anna Łukaszewska', Radosław Łysek ${ }^{2}$, \\ Renata Wolfshaut-Wolak ${ }^{2}$, Piotr Bogacki ${ }^{3}$, Janusz Grodecki ${ }^{4}$, Ewa Mirek-Bryniarska ${ }^{5}$, \\ Jadwiga Nessler ${ }^{6}$, Piotr Podolec ${ }^{7}$, Kalina Kawecka-Jaszcz ${ }^{1}$, Andrzej Pająk ${ }^{2}$

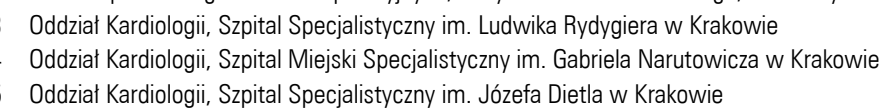

\section{SŁOWA KLUCZOWE}

cholesterol, choroba wieńcowa, ryzyko sercowo-naczyniowe, wtórna prewencja
Adres do korespondencij: prof. dr hab. n. med. Piotr Jankowski, I Klinika Kardiologii, Elektroterapii Interwencyjnej i Nadciśnienia Tętniczego, Uniwersytet Jagielloński, Collegium Medicum, ul. Kopernika 17, 31-501 Kraków, tel.: 1242473 00, e-mail: piotrjankowski@interia.pl Praca wpłynęła: 20.03.2016. Przyjęta do druku: 24.05.2016. Publikacja online: 23.06.2016. Nie zgłoszono sprzeczności interesów.

Pol Arch Med Wewn. 2016; 126 (6): 388-394 doi:10.20452/pamw.3447 Copyright by Medycyna Praktyczna, Kraków 2016

\section{STRESZCZENIE}

WPROWADZENIE U pacjentów ze zdiagnozowaną chorobą niedokrwienną serca (ChNS) ryzyko występowania kolejnych zdarzeń sercowo-naczyniowych jest duże.

CELE Celem badania była ocena czynników związanych z kontrolą hipercholesterolemii u osób po hospitalizacji z powodu ChNS.

PACJENCI I METODY Do badania włączano kolejnych pacjentów z 5 szpitali z oddziałami kardiologicznymi jednego z miast w południowej Polsce. Pacjenci byli hospitalizowani z powodu ostrego zespołu wieńcowego lub w celu rewaskularyzacji mięśnia sercowego. Rekrutację do badania oraz wywiad przeprowadzono 6-18 miesięcy po hospitalizacji.

WYNIKI Ogółem 83,6\% pacjentów zażywało statyny, 2,1\% - fibraty, a 0,5\% - ezetymib. Statynę w dużej dawce ( $\geq 40 \mathrm{mg}$ atorwastatyny lub $\geq 20 \mathrm{mg}$ rozuwastatyny) stosowało 36,1\% uczestników badania. Wiek i hospitalizacja w szpitalu akademickim były istotnie związane z większym prawdopodobieństwem stosowania statyny. Ogótem $28,1 \%$ pacjentów miało dobrze kontrolowaną hipercholesterolemię (cholesterol LDL $<1,8 \mathrm{mmol} / \mathrm{l})$, natomiast u $71,9,38,6,24,4$ oraz $10,3 \%$ stężenie cholesterolu wynosiło odpowiednio $\geq 1,8, \geq 2,5, \geq 3,0$ oraz $\geq 4,0 \mathrm{mmol} / \mathrm{l}$. Młodszy wiek, wysokie ciśnienie tętnicze i wysokie stężenie glukozy na czczo wiązały się z częstością występowania stężenia cholesterolu $L D L \geq 1,8 \mathrm{mmol} / \mathrm{l}$, natomiast młodszy wiek, krótki czas trwania edukacji, brak aktywności zawodowej, brak udziału w rehabilitacji kardiologicznej oraz wysokie ciśnienie tętnicze wiązały się z częstością występowania stężenia cholesterolu $\mathrm{LDL} \geq 4,0 \mathrm{mmol} / \mathrm{l}$.

WNIOSKI Na częstość stosowania statyn wpływają wiek i czynniki związane z organizacją systemu opieki zdrowotnej, natomiast kontrolę hipercholesterolemii po hospitalizacji z powodu ChNS warunkują przede wszystkim czynniki demograficzne i kliniczne. 